\title{
The Institute of Chemistry
}

\author{
By Dr. Bernard Dyer
}

$\mathrm{N}^{\mathrm{B}}$ EXT week the Institute of Chemistry will celebrate by a banquet and a reception the fiftieth anniversary of the granting of the Royal Charter which, in 1885, rewarded its already many years of effort to establish a definite form of recognition of the profession of chemistry as distinguished from the calling of pharmacy, with which in the lay mind it has been too often confused.

Before the letters F.I.C. or A.I.C. were used to designate fellows or associates of the Institute, there was no specific label by which the analytical and consulting chemist, the teacher of chemistry or the chemical research worker could briefly suggest the nature of his profession, except the vaguely significant letters indicative of fellowship of the Chemical Society-awarded not altogether without discrimination, but carrying with it no diplomatic significance; for the charter of the Chemical Society gave it no power to confer an examinational qualification.

In the late 'sixties and early 'seventies of last century, the desirability of some such distinction was, from time to time, discussed at formal and informal meetings, and in letters and articles in the Press ; and in 1875, on the initiative of F. A. Manning, a well-known London analyst, a small organisation committee was formed to endeavour to formulate a definite plan of action. This committee was, from time to time, enlarged and reconstructed, and divers proposals were considered, with the result that two years later, in 1877, the Institute of Chemistry was incorporated under licence of the Board of Trade.

The first president was Prof. (later Sir Edward) Frankland (of the Royal School of Mines), and the other original subscribers to the deed of incorporation were Prof. Abel, Dr. Angus Smith, Prof. J. H. Gladstone, Prof. E. V. Tuson, Prof. W. Noel Hartley, F. A. Manning, E. Neison (later E. N. Nevill), Prof. Galloway, C. T. Kingzett, Prof. J. Attfield, Dr. C. A. Alder Wright, Dr. James Bell, Michael Carteighe, Prof. Crum Brown, and Prof. (later Sir) William Crookes. Of these signatories it is pleasant to be able to record that two are still with us, namely, Mr. E. N. Nevill (known to us then as Neison) and Mr. Charles $\mathrm{T}$. Kingzett. Many chemists who had already given support to the movement in its preliminary stages were registered as original fellows, while admission was offered for the next six months to all whose positions or other evidence of fitness should commend them to the Council. After this, admission was to be restricted to applicants who had gone through a definitely stipulated course of training and experience; and the passing of a practical examination held by the Institute itself was soon prescribed as an additional requirement.

It was during these first six months that the writer of these notes-already in practice as a consultant at an age which would, in these days, surely seem precocious-was elected; but, as he remembers, he had at first to be satisfied with the rank of associate, until he attained the full age of twenty-four years fixed for admission to the title of fellowship. This, otherwise insignificant, incident is mentioned merely to indicate the duration of his association with the Institute and its activities, which is his excuse for yielding to the editorial invitation to occupy this space. The number of fellows and associates of the Institute recorded at the end of its first year was only 275 . To-day its roll extends to considerably more than 6,000 .

After three years, Prof. Frankland was succeeded as president by Sir Frederick Abel, who in turn was followed in 1883 by Prof. Odling, of Oxford, to whom fell, in 1885, the pleasure of announcing the reception of the Royal Charter, the grant of which forms the subject of the forthcoming Jubilee Celebration. The next president was Dr. James Bell who, in turn, was followed by Prof. (afterwards Sir William) Tilden, during whose time (1891-94), after a nomadic existence in temporary offices and reliance on the hospitality of the Chemical Society for general meetings, the Institute became possessed of a home of its own in Bloomsbury Square. It was also during Tilden's presidency that the Council was fortunate in obtaining the services in its secretarial office of a modest young man named R. B. Pilcher. The post of secretary and registrar had, from the beginning, been filled by Charles E. Groves (the well-known editor of the Journal of the Chemical Society) who had recently retired, being succeeded by $\mathrm{Mr}$. G. H. Robertson, whose term of office, however, was cut short by illness. For the time being, Prof. J. Millar Thomson assumed the office of honorary registrar and secretary, with $\mathrm{Mr}$. Pilcher as his lieutenant, and later (in 1900), when Thomson 
became president, the full title of registrar and secretary fell to Mr. Pilcher, to whose zeal and energy the Institute owes not a little of its development and usefulness during the last thirty-five years.

Prior to Thomson's elevation to the chair, two other presidents had succeeded Tilden, namely, Dr. W. J. Russell (of St. Bartholomew's Hospital) and Sir Thomas Stevenson, the distinguished toxicologist. The presidency of the latter is chiefly memorable for the institution of the special examination in the analysis of food, drugs and water, and in microscopy, pharmacology and therapeutics, designed to meet the requirements of the Local Government Board (now the Ministry of Health), in considering the qualifications of candidates for appointment as public analysts, and the special diploma of the Institute has ever since been accepted by the Ministry as evidence of competency in this special work.

Succeeding presidents of the Institute were David Howard, Prof. Percy Frankland, Sir George Beilby and Prof. Raphael Meldola. It was during the term of office of the latter that, the lease of the Bloomsbury Square house having expired, the Institute migrated into the present commodious premises which, with the help of a generously supported building fund, it had been able to erect in Russell Square.

Meldola was succeeded in the chair by Sir James Dobbie (the then Government Chemist), whose influence helped to effect a long-contemplated and momentous change in the regulations for admission to the associateship. Hitherto all candidates had to be examined by the Institute itself, but it was then decided that the attainment of high chemical honours at the degree examination of any recognised university should be accepted as sufficient qualification. Promotion to the fellowship, however, was still, as now, to be awarded only after subsequent experience and the passing of a final examination in a special branch of chemistry, pure or applied, unless in exceptional cases in which the carrying out of advanced research, or the rendering of other signal service to chemistry, might be regarded by the Council as justifying exemption.

Later names on the list of past presidents are those of Sir Herbert Jackson, A. Chaston Chapman, Prof. G. G. Henderson, Prof. A. Smithells and Sir Christopher Clayton, while the now acting president is Prof. Jocelyn F. Thorpe (of the Imperial College) who has recently had the satisfaction of announcing that in celebration of its Charter Jubilee the King has been graciously pleased to accord to the Institute His Royal Patronage.

To attempt here any adequate indication of the present multifarious activities of the Institute would be futile; but it should be recorded that it has in Great Britain and in Ireland fourteen local sections, and at least five in the Dominions, all of which hold local meetings for the delivery of lectures and the discussion of papers, while in London advanced 'Memorial' lectures are given from time to time by eminent masters of special branches of science or of technology. The Council is always ready to lend advisory aid in administrative or other matters of public importance in which chemical considerations are involved, and sends representatives or delegates to many external conferences or standing committees. Not the least of the episodes in its history calling for retrospective satisfaction is the very multifarious help, civil as well as military, which, collectively as well as by individual effort, the Institute was able to render to the country during the War.

It should be added that the Institute issues a quarterly journal which records the proceedings of the Council and the activities of the various local sections and other items of domestic interest ; and, in addition, often includes editorial articles which are not only informative but also healthily stimulative.

\section{Obituary}

Dr. C. E. St. John

CHARLES EDWARD ST. JOHN, who died on April 26 of pneumonia after a short illness, was one of the most lovable of men. Born on March 15, 1857, at Allen, Michigan, he graduated at the Michigan State University and studied afterwards at Harvard and Berlin. He was an instructor in physics at the Michigan State University and in 1897 became assistant professor, and later professor, of physics and astronomy at Oberlin College, and later dean of the College of Arts and Sciences. In the midst of these busy duties he found time in the summer to work at the Yerkes Observatory with Nichols on the measurement of radiation from the stars. At fortynine years of age he joined Hale at the Mount Wilson Observatory and remained on the staff there until 1929 when he retired. $\mathrm{He}$ was made a research associate in 1930 and continued actively working, despite failing health, until the end, his last piece of work (left unfinished) being a general discussion of the problem of solar rotation.

It is as an enthusiastic and most successful 